\title{
SOCIAL RESPONSIBILITY PERGURUAN TINGGI ISLAM DALAM MASYARAKAT HETEROGEN DI KOTA PALOPO
}

\author{
Zainuddin S \\ IAIN Palopo \\ Jl. Agatis, Kelurahan Balandai, Kota Palopo, Sulawesi Selatan, Indonesia \\ E-mail: zainuddin.s@iainpalopo.ac.id
}

\begin{abstract}
Social Responsibility Islamic college in a heterogeneous society is very important where there are various permaslahan ranging from social, religious, cultural, ethnic, and so on. Implementation of social responsibility programs implemented by IAIN college Palopo in the form of community service programs through research and community empowerment as a portion of Tridharma college. Various problems and constraints faced by IAIN Palopo is the lack of cooperation with the government, the lack of coordination of the implementation of activities, disseminate the results of research which is still low, the lack of real information regarding the condition of society, the implementation of the work program based on individual initiative, work programs aimed at specific groups, and there has been no work program, appropriate and sustainable for society.
\end{abstract}

Keywords: Social Responsibility, Islamic College, Heterogeneous society

\begin{abstract}
Abstrak
Sosial responsibilty perguruan tinggi Islam dalam masyarakat yang heterogen merupakan hal yang sanghat krusial dimana terdapat berbagai permaslahan mulai dari sosial kemasyarakatan, agama, budaya, etnis dan sebagainya. Implementasi program sosial responsibility perguruan tinggi dilaksanakan oleh IAIN/STAIN Palopo dalam bentuk program pengabdian masyarakat melalui penelitian dan pemberdayaan masyarakat sebagai bahagian dari tridarma perguruan tinggi. Berbagai permasalahan dan kendala yang dihadapai oleh IAIN/STAIN Palopo diantaranya kurangnya kerja sama dengan pihak pemerintah, koordinasi pelaksanaan kegiatan masih minim, sosialisasi hasil penelitian yang masih minim, kurangnya informasi real terkait kondisi masyarakat, pelaksaan program kerja berdasarkan inisiatif individu, program kerja ditujukan kepada golongan tertentu, serta belum terdapat program kerja yang tepat guna dan berkesinambungan bagi masyarakat.
\end{abstract}

Kata Kunci,: Social Responsibility, Perguruan Tinggi Islam, Masyarakat Heterogen

\section{PENDAHULUAN}

Heterogenitas dalam masyarakat akan memberikan warna tersendiri dalam seluruh aspek kehidupan bernegara. Perbedaan dalam dimensi kehidupan sosial tersebut merupakan identitas kebangsaan yang patut dibanggakan karena merupakan kekayaan bangsa yang tidak dimiliki oleh bangsa di negara lain yang dihimpun dalam binekatunggal ika. Kebhinekaan 


\section{2 | Zainuddin $S$}

itu dapat menciptakan integrasi nasional apabila dikelola dan dipelihara secara baik meskipun di satu sisi konsekuensi logis yang harus diterima dari negara kesatuan atas kebangsaan yang heterogen adalah resiko terpolarisasi dan ancaman timbulnya disintegrasi antar kelompok sosil.

Keberadaan Perguruan tinggi ditengah masyarakat merupakan salah satu subsistem pendidikan nasional yang memiliki kewajiban dan berperan penting dan strategis melalui implementasi Tri Dharma Perguruan Tinggi, yaitu pendidikan, penelitian, dan pengabdian kepada masyarakat sebagaimana diatur dalam Undang-Undang Nomor 20 Tahun 2003 tentang Sistem Pendidikan Nasional menyebutkan bahwa perguruan tinggi berkewajiban menyelenggarakan pendidikan, penelitian, dan pengabdian kepada masyarakat (Pasal 20 Ayat 2). ${ }^{1}$ Sebagaimana diamanatkan dalam UU Nomor 14 Tahun 2005 tentang Guru dan Dosen, dan Peraturan Pemerintah Republik Indonesia Nomor 37 Tahun 2009 tentang Dosen, disebutkan bahwa dosen adalah pendidik profesional dan ilmuwan dengan tugas utama mentransformasikan, mengembangkan dan menyebarluaskan ilmu pengetahuan, teknologi, dan seni melalui pendidikan, penelitian dan pengabdian kepada masyarakat.

Keprofesionalan dosen sebagai bagian dari suatu perguruan tinggi melaksanakan tugas dan tanggungjawabnya baik secara intern ataupun ekstern institusi/perguruan tinggi dapat diartikan sebagai suatu pekerjaan atau kegiatan yang dilakukan yang merupakan sumber pendapatan untuk memenuhi kebutuhan hidupnya yang membutuhkan kecakapan, keahlian dan kemahiran yang memenuhi standar kualitas yang berlaku serta dilakukan sesuai dengan norma, kode etik dan pendidikan profesi. Pelaksanaan kegiatan profesional dosen terbagi atas tiga fungsi yang dikenal sebagai Tri Dharma Perguruan tinggi yang merupakan kewajiban yang melekat pada diri dosen sebagai perwakilan perguruan tinggi ditengah kehidupan sosial kemasyarakat sebagaimana yang diamanatkan oleh Undang-undang harus memiliki kompetensi diantaranya pedagogik, kepribadian, sosial dan profesional.

Bangsa Indonesia adalah bangsa yang sangat besar dan multikultural dan memiliki permasalahan sosial yang cukup kompleks, baik dari segi interaksi sosial, budaya, ekonomi dan sebagainya memberikan konstribusi tersendiri dalam seluruh aspek kehidupan baik dari sosial, Ekononomi, teknologi dan bahkan ilmu pengetahuan sehingga memberi ruang terjadinya berbagai perbedaan dan kesamaan yang memungkin menjadi sumber daya dan konflik sosialm dalam pengembangan dan pembangunannya. 2003).

1 Republik Indonesia, “Undang-Undang Nomor 20 Tahun 2003” (Sekretariat Negara, 
Penelitian ini mencakup pada keterlibatan dan konstribusi dosen dan mahsiswa STAIN/IAIN Palopo baik secara langsung maupun tidak langsung sesuai dengan disiplin ilmu yang dimilki dalam melaksanakan kegiatan penelitian dan pengabdian kepada masyarakat dengan tujuan memberikan konstribusi dalam penyelesaian berbagai permasalahan sosial kemasyarakatan yang dihadapi oleh pemerintah kota palopo sesuai dengan tingkat prioritasnya.

\section{MASYARAKAT HETEROGEN}

Clifford Geertz seorang ahli politik barat mengatakan bahwa Keberagaman masyarakat Indonesia ini sedemikan kompleksnya sehingga sulit melukiskan anatominya secara persis. Geertz menggambarkan heteroginitas masyarakat yakni : ${ }^{2}$

"Negeri ini bukan hanya multi etnis (Jawa, Batak, Bugis, Aceh, Flores, Bali dan seterusnya), melainkan juga menjadi arena pengaruh multi mental (India, Cina, Belanda, Portugis, Hindhuisme, Buddhisme, Konfusianisme, Islam, Kristen, Kapitalis, dan seterusnya). Indonesia adalah sejumlah bangsa dengan ukuran, makna dan karakter yang berbeda-beda yang melalui sebuah narasi agung yang bersifat historis, ideologis, religius atau semacam itu disambung-sambung menjadi sebuah struktur ekonomis dan politis bersama."

Pernyataan Geertz tersebut di atas memberikan penegasan bahwa Indonesia merupakan sebuah negeri yang kompleks dan heterogen. Masyarakat Indonesia adalah masyarakat yang beragaman dan tercermin dari adanya kelompok hidup masyarakat yang memiliki kesamaan serta perbedaan budaya, suku, kesamaan keyakinan-keyakinan, unsur-unsur biologis dalam kesatuan ras dan lain yang menjadi identitas kelompoknya dan kultur dalam masyarakat.

Pemahaman mengenai kultur juga diungkapkan oleh Conrad P. Kottak bahwa: Kultur adalah sebuah simbol. Dalam hal ini simbol dapat berbentuk sesuatu yang verbal dan non-verbal, dapat juga berbentuk bahasa khusus yang hanya dapat diartikan secara khusus pula atau bahkan tidak dapat diartikan ataupun dijelaskan. ${ }^{3}$

Keberagaman dalam masyarakat itu memuat suatu idealitas multikulturalisme. Artinya bahwa pengakuan dan penerimaan terhadap segala bentuk perbedaan dan persamaan yang terdapat dalam masyarakat yang majemuk dan heterogen merupakan sesuatu keniscayaan yang mutlak dibenarkan yang merupakan stakeholder sebuah lembaga pendidikan.

${ }^{2}$ Will Kymlicka, Kewarganegaraan Multikultural (Jakarta: LP3ES, 2003), 4.

3 M Ainul Yaqin, Pendidikan Multikultur (Yogyakarta: Pilar Media, 2005), 7. 


\section{4 | Zainuddin $S$}

Pengertian stakeholder menurut Gray et al. (2001) adalah pihak-pihak yang berkepentingan pada perusahaan dan dapat mempengaruhi aktivitas perusahaan 4 . Hal ini juga dapat berlaku pada perguruan tinggi yang merupakan intitusi pendidikan dimana terdapat stakehoder merupakan pihak yang memiliki kepentingan atas produk yang dihasilkan oleh perguruan tinggi. Para stakeholder yang paling memiliki kepentingan terhadap institusi ialah masyarakat, Perusahaan swasta maupun milik negara ataupun daerah, pemerintah, pasar modal, dan lainlain. Dengan demikian, keberadaan suatu institusi atau lembaga pendidikan sangat dipengaruhi oleh dukungan yang diberikan oleh stakeholder atau pun sebaliknya. Gray, Kouhy dan Adams (1994, p 53) dalam Ghozali dan Chariri (2007) mengatakan bahwa Kelangsungan hidup perusahaan tergantung pada dukungan stakeholder dan dukungan tersebut harus dicari sehingga aktivitas perusahaan adalah untuk mencari dukungan tersebut. 5 Makin besar bentuk dukungan stakeholder (dalam hal ini masyarakat sekitar organisasi), makin besar pula usaha yang dilakukan oleh institusi untuk melakukan penyesuaian dalam mengimplementasikan tugas dan tanggung jawabnya sebagai wadah pengembangan ilmu pengetahuan dalam menyelesaikan permasalahan sosial dalam masyarakat dianggap sebaagi bagian dari dialog antara perusahaan dengan stakeholder-nya.

\section{SOCIAL RESPONSIBILITY}

Social responsibility atau tanggung jawab sosial merupakan sebuah bentuk pertanggungjawaban suatu organisasi atau institusi terhadap stakeholder atas pemanfaatan sumber daya dalam melaksanakan kegiatan operasionalnya. Kebijakan pemerintah pemerintah untuk mewajibkan kepada organisasi perusahaan melaksanakan tanggungjawab sosial terhadap masyarakat atau lebih dikenal sebagai corporate social responsibilit (CSR) telah ditetapkan dalam Undang-undang No. 40 tahun 2007 Tentang CSR yang tepatnya pada pasal 74, yang mengisyaratkan bahwa para pelaku usaha diwajibkan untuk melaksanakan program CSR. Namun dalam pada kenyataannya, terdapat permasalahan-permasalahn yang dihadapi karena terdapat kepetingan pihak tertentu sehingga tujuan dari pelaksanaan CSR nyaris kehilangan arah. Hal ini ditunjukkan dengan pelaksanaan CSR cenderung diidentikkan kedalam bentuk kegiatan untuk pencitraan bagi para pelaku usaha atau organisasi tertentu kepada masyarakat. Padahal makna dari CSR idealnya sebagai suatu bentuk kegiatan yang dilakukan oleh pelaku usaha atau organisasi untuk berbagi keuntungan atas dampak sosial pada suatu daerah yang diakibatkan dari proses produksi yang dilakukan oleh organisasi atau perusahaan yang digunakan untuk peningkatan kualitas

4 Ratnasari Yunita, Pengaruh Corporate Governance Terhadap Luas Pengungkapan Tanggung Jawab Sosial Perusahaan Di Dalam Sustainability Report (Semarang: Universitas Diponegoro, 2013), 31.

5 Ibid.

PALITA: Journal of Social-Religi Research 
kehidupan masyarakat dan lingkungannya. Hilangnya makna dan kegunaan CSR ini utamanya dikarenakan oleh persepsi para pelaku usaha atau organisasi sebagai suatu biaya tambahan (additional costs) sehingga berdampak pada penurunan keuntungan yang diperoleh perusahaan.

Menurut Teguh S. Pambudi dalam Widyantoro, dkk (2009) menyatakan ada lima pilar konsep CSR, yaitu; Pertama, building human capital, sosial, lingkungan menyangkut kemampuan perusahaan untuk memiliki dukungan sumber daya manusia yang handal (internal). Disisi ini perusahaan dituntut untuk melaksanakan pemberdayaan masyarakat, biasanya melalui community depelopment. kedua, strengthening economies, memberdayakan ekonomi komunitas. Ketiga, assessing social, perusahaan menjaga keharmonisan dengan masyarakat sekitar agar tidak menimbulkan konflik. Keempat, encouraging good governance. Perusahaan dikelola dalam tata pamong/birokrasi yang baik. Kelima, procteting the environment, perusahaan harus mengawal kelestarian lingkungan6.

Sementara A.B. Susanto (2007) mengemukakan bahwa dari sisi perusahaan terdapat 5 (lima) manfaat yang dapat diperoleh dari aktivitas CSR, yaitu :

1. Mengurangi resiko dan tuduhan terhadap perlakuan tidak pantas yang diterima perusahaan.

2. CSR dapat berfungsi sebagai pelindung dan membantu perusahaan meminimalkan dampak buruk yang diakibatkan suatu krisis.

3. Keterlibatan dan kebanggaan karyawan.

4. CSR yang dilaksanakan secara konsisten akan mampu memperbaiki dan mempererat hubungan antara perusahaan dengan para stakeholdernya.

5. Meningkatkannya penjualan, karena konsum ${ }^{7}$

Tanggung Jawab Sosial Universitas sebagai terjemahan dari Universitas Sosial Responsibility (USR) dalam konteks ini merupakan analogi dari istilah Corporote Social Responsibilty (CSR) yang sering diterjemahkan dengan Tanggung Jawab Sosial Perusahaan. Dengan menimbang bahwa perguruan tinggi/universitas berkarakteristik organisasi nirlaba, maka istilah corporate menjadi sesuai dengan kegiatan produksi barang atau jasa sehingga digunakan istilah universitas walaupun secara hakikat tetap melakukan produktivitas.

Dengan perkembangan berbagai konsep mengenai CSR, maka tanggung jawab sosial universitas saat ini telah terjadi perubahan yang cukup signifikan. Tanggung jawab sosial universitas bukan hanya sekedar sebagai produsen atau laboratorium ilmu pengetahuan, pendidikan, penelitian,

${ }^{6}$ Agus Widyantoro and M. Hadi Subhan, Tanggung Jawab Sosial Institusi Perguruan Tinggi (Institution Social Responsibility) Sebagai Upaya Mewujudkan Susteinablity Development Bagi Masyarakat Lingkar Kampus (Surabaya: Universitas Airlangga, 2009). 2007).

${ }^{7}$ A.B.Susanto, Corporate Social Responsibility (Jakarta: The Jakarta Consulting Group, 
pengajaran, pengabdian masyarakat, kebebasan mimbar akademis, tetapi telah bertransformasi ke dalam kehidupan masyarakat secara aktif. Bahkan, di mata masyarakat kini perguruan tinggi/universitas telah dianggap sebagai institusi yang serba bisa, ampuh dan paten serta dipercaya dalam menjawab permasalahan dan perubahan yang terjadi dalam kehidupan masyarakat ${ }^{8}$

Perlaksanaan social responsibility oleh perguruan tinggi yang dijabarkan dalam tridarma perguruan tinggi khususnya pengadian pada masyarakat merupakan bentuk pengimplementasian tanggungjawab sosial institusi atau lebih dikenal sebagai corporate social responsibility (CSR). Pertanggungjawaban sosial merupakan bagian yang tak gerpisahkan dari seluruh kegiatan organisasi untuk melakukan interaksi dan pemersatuan organisasi dan lingkungan sosial kemasyarakatan serta stakeholder lainnya.

Corporate Social Responsibility (CSR) mencakup pengertian yang lebih luas, menuju Social Responcibility dan Social Leadership. Social Responcibility (CSR) merupakan keseriusan organisasi mempertimbangkan dampak yang terjadi dalam masyarakat ${ }^{9}$. Kemudian Tanggungjawab sosial dapat pula diartikan sebagai kewajiban perusahaan untuk merumuskan kebijakan, mengambil keputusan, dan melksanakan tindakan yang memberikan manfaat kepada masyarakat ${ }^{10}$.

Philip Kotler, menyebutkan terkait CSR dalam bukunya yang berjudul Doing the Most Good for Your Company and Your Cause, mengungkapkan berbagai alasan perlunya perusahaan atau organisasi menggelar aktivitas atas tanggungjawab sosial. Disebutkannya, CSR bisa membangun positioning merek, mendongkrak penjualan, memperluas pangsa pasar, meningkatkan loyalitas karyawan, mengurangi biaya operasional, serta meningkatkan daya tarik korporat di mata stakeholder. ${ }^{11}$

\section{TRIDHARMA PERGURUAN TINGGI}

Perguruan tinggi merupakan intitusi atau organisasi satuan pendidikan yang melaksanakan pendidikan tinggi yang dalam penyelenggaraannya melaksanakan tiga fungsi yang dikenal sebagai tridarma perguruan tinggi yaitu pendidikan, penelitian dan pengabdian sebagaimana tercantum dalam pada undang-undang Repoblik Indonesia nomor 12 tahun 2012 tentang perguruan tinggi.

\footnotetext{
${ }^{8}$ Carunia Mulya Firdausy, "Tanggung Jawab Sosial Universitas (Usr) Dan Pengalaman Ristek Dalam Membangun Masyarakat Berbudaya Iptek," Kompasiana, December 8, 2009.

${ }_{9}^{9}$ Amin Widjaja Tunggal, Corporate Social Responcibility (Jakarta: Haryindo, 2008), 30.

10 Ibid., 61.

11 Philip Kotler, Doing the Most Good for Your Company and Your Cause (New York: Thomas Dunne Books, 2007), 33.
} 
Perguruan tinggi memilki unsur yang cukup dalam mengemban fungsinya diantaranya dosen, mahasiswa dan tenaga akadmik. Proses untuk menemukan suatu kebenaran secara ilmiah mempunyai implikasi etis bagi seorang dosen yang merupakan salah satu unsur dalam suatu perguruan tinggi. Kegiatan intelektual yang digelutinya akan memberikan dampak pada keyakinan atas kebenaran yang dapat diterima dalam masyarakat. Kebenaran berfungsi bukan saja sebagai jalan pikirannya namun seluruh jalan hidupnya ${ }^{12}$.

Perguruan tinggi diwakili oleh dosen melaksanakan kegiatannya diatur dalam Undang-undang Guru dan Dosen No.4 Tahun 2005 tentang Guru dan Dosen. Dalam Pasal 3, ayat 1 dikemukakan mempunyai kedudukan sebagai tenaga yang professional pada jenjang pendidikan tinggi yang diangkat sesuai dengan peraturan perundang-undangan yang berlaku. Lebih jauh dikemukakan bahwa dosen merupakan pendidik profesional dan ilmuwan dengan tugas utama menstransformasikan, mengembangkan, dan menyebarluaskan ilmu pengetahuan yang dimiliki, teknologi, dan seni melalui pendidikan, penelitian, dan pengabdian kepada masyarakat

Dalam usaha masyarakat untuk menegakkan kebenaran inilah maka perguruan tinggi akan merasa terpanggil oleh kewajiban sosialnya sebagai bentuk pengabdian yang diamanatkan oleh undang-undang, bukan hanya sebagai lembaga analisator materi kebenaran diberbagai disiplin ilmu yang dimiliki namun juga sebagai prototipe moral yang baik serta menjadi motivator dan inisiator kegiatan sosial kemasyarakatan pada suatu wilayah. Pengabdian kepada masyarakat oleh perguruan tinggi dengan demikian harus mencakup beberapa aspek ${ }^{13}$ :

1. Pengembangan ilmu pengetahuan, teknologi dan seni;

2. Penyebar luasan ilmu pengetahuan, teknologi dan seni;

3. Penerapan ilmu pengetahuan, teknologi dan seni;

4. Pemberian bantuan keahlian kepada masyarakat;

5. Pemberian jasa pelayanan profesional kepada masyarakat.

Implementasi sosial responsibility (pengabdian kepada masyarakat) bertujuan memberikan respon atas permasalahn soaial masyarakat yang dihadapi dan berkontribusi dalam memenuhi dan meningkatkan berbagai kebutuhan masyarakat serta yang pada akhirnya masyarakat dapat hidup mandiri dan lebih baik.

12 Jujun Suriasumantri S, Filsafat Ilmu Sebuah Pengantar (Jakarta: Pustaka Sinar Harapan, 1998), 244.

${ }^{13}$ Agussalim Sitompul, Pengabdian Kepada Masyarakat Bagi Perguruan Tinggi Agama Islam - Sudin Pengabdian Kepada Masyarakat Bagi Perguruan Tinggiagama Islam.pdf (Yogyakarta: P3M IAIN Sunan Kalijaga, 1993), 132-33. 


\section{8 | Zainuddin $S$}

Margono Slamet menyebutkan bahwa tujuan perguruan tinggi melaksanakan pengabdian kepada masyarakat antara lain 14 :

1. Mempercepat proses peningkatan kemampuan sumberdaya manusia sesuai dengan dinamika pembangunan;

2. Mempercepat upaya pengembangan masyarakat ke arah terbinanya masyarakat dinarnis;

3. Mempercepat upaya pembinaan institusi dan profesi masyarakat sesuai dengan perkembangannya dalam proses modernisasi.;

4. Memperoleh umpan balik dan masukan lain bagi perguruan tinggi yang dapat dipergunakan untuk meningkatkan relevansi pendidikan dan penelitian yang dilakukannya dengan kebutuhan situasi

Menurut Khairuddin terdapat beberapa kegiatan yang dapat dilakukan oleh perguruan tinggi dalam melaksanakan kegiatan pengabdian sebagai bentuk komitmennya dalam mengembangkan sumber daya serta mengembangkan pembangunan diantaranya

1. Pengembangan desa binaan

2. Pelatihan masyarakat di dalam dan luar kampus

3. Local verifivation trial

4. Pelaksanaan KKN, dan sebagainya ${ }^{15}$.

\section{IMPLEMENTASI PENELITIAN DAN PENGABDIAN PADA MASYARAKAT}

Pelaksanaan program tridarma perguruan tinggi oleh IAIN/STAIN Palopo telah dilaksanakan melaui berbagai program yang terencana baik dari segi pendidikan dan pengajaran, penelitian pengembangan keilmuan dan sumber daya, maupun pengabdian kepada masayarakat sebagai bentuk pertanggungjawaban sosial pihak lembaga pendidikan dalam mengambangkan ilmu pengetahuan dan tehknologi yang lebih dikenal dengan universitas soscial responsibility (USR).

Implementasi USR oleh pihak IAIN/STAIN Palopo melalui Program pengabdian kepada masyarakat dan penelitian yang dilaksanakan berupa penelitian pengembangan bidang keilmuan maupun penelitian berbasis pengabdian dalam rangka pengembangan potensi daerah yakni sumber daya manusia maupun sumber daya lainnya yang dimiliki daerah khususnya kota palopo dalam menunjang tercapainya tujuan pembangunan daerah. Kegiatan ini secara langsung maupun tidak langsung akan memberikan konstribusi positif yang berdampak pada kelangsungan hidup bagi masyarakat yang

14 Margono Slamet, Metodologi Pengabdian Pada Masyarakat (Yogyakarta: P3M IAIN Sunan Kalijaga, 1993), 36.

15 Khairuddin, Implementasi Tridarma Perguruan Tinggi Dalam Mendukung Disiplin Nasional (Sumatra Utara: Universitas Sumatera Utara, 2004). 
memiliki berbagai permasalahan sosial baik secara vertikal berupa intern kelompok sosial maupun seacara horisantal antar kelompok sosial lainnya yang sifatnya heterogen dan memiliki kompleksitas masalah sosial yang cukup tinggi. Disamping pelaksanaan penelitian yang berbasis pengabdian IAIN/STAIN Palopo juga melaksanakan program pengabdian secara aktif kepada masyarakat melaui tenaga pegajar dalam hal ini adalah dosen maupun mahasiswa yang secara proaktif terlibat diberbagai kegiatan sosial. Berbagai kegiatan yang dilakukan oleh pihak lembaga diantaranya melaksanakan penelitian terhadap fenomena sosial kemasyarakatan, melaksanakan pendapingan keagamaan berupa pembentukan kelompok kajian dan majelis, pelaksanaan pencerahan melalui kegiatan keagamaan lainnya serta pembetukan desa binaan.

Kegiatan yang dilaksanaan dalam rangka pengembangan daerah khusus kota Palopo selayaknya mendapatkan perhatian dari pihak institusi atas berbagai masalah sosial kemasayarakatan oleh pihak institusi agar tercipta hubungan yang harmonis dengan pemerintah setempat dalam membangun dan mengembangkan potensi daerah dengan menjalin hubungan kerjasama dan berkonsultasi berbagai informasi yang menjadi fokus dan perioritas bagi pemerintah daerah. Berikut tabel hasil tabulasi pendapat/pernyataan responden terkait hubungan kerjasama IAIN/STAIN Palopo dengan pemerintah kota pada tingkat kelurahan dalam pelaksanaan kegiatan penelitian pengembangan ilmu pengetahuan dan pengabdian kepada masyarakat di kota Palopo. Tabulasi pernyataan/pendapat masyarakat kota palopo terkait hubungan kerjasama antara pemerintah dan pihak IAIN/STAIN Palopo dalam melaksanakan program tanggungjawab sosial perguruan tinggi dapat dilihat pada Tabel 1 berikut:

Tabel 1. Kerjasama dan Konsultasi antara IAIN/STAIN Palopo dengan masyarakat Kota Palopo

\begin{tabular}{|l|c|c|}
\hline \multicolumn{1}{|c|}{ Uraian } & Jumlah responden & Persentase (\%) \\
\hline Sangat baik & 0 & 0 \\
\hline Baik & 1 & 2,5 \\
\hline Cukup & 2 & 5,0 \\
\hline Kurang & 5 & 12,5 \\
\hline Sangat kurang & 32 & 80,0 \\
\hline Jumlah & 40 & 100 \\
\hline
\end{tabular}

Sumber hasil olah data penelitian 2015

Berdasarkan Tabel 1 tersebut, pelaksanaan kegiatan USR IAIN/STAIN Palopo belum terlaksana secara maksimal hal ini ditunjukkan terdapat 80 persen dari responden menjawab belum terdapat kejasama dan konsultasi antar institusi dengan pemerintah setempat dalam hal ini kelurahan dan 
kecamatan dalam mengatasi permasalahan sosial di masyarakat. hal ini mengindikasikan bahwa dosen dan mahasiswa melaksanakan kegiatan pengabdian dan penelitian di masyarakat tidak sesuai dengan harapan dan kebutuhan masyarakat.

Menurut Rusdianto salah satu pihak kelurahan mengemukakan pendapatnya bahwa :

"hubungan kerjasama antara lembaga pemerintah dan instansi pemerintah dalam rangka pelaksanaan program penelitian dan pengabdian kepada masyarakat merupakan hal yang penting untuk dilakukan agar dapat saling berbagi informasi tentang kondisi rill yang ada dalam masyarakat baik dari segi masalah yang dihadapi oleh masyarakat itu sendiri maupun alternatif penyelesaian atas problem sosial kemasyarakatan sehingga program yang akan dilaksanakan memberikan konstribusi terhadap pembangunan daerah ". 16

Keberadaan program penelitian dan pengabdian yang dilaksanakan oleh pihak IAIN/STAIN Palopo kurang dirasakan manfaatnya secara maksimal oleh masyarakat/pemerintah setempat dikarenakan terkadang data yang diperoleh oleh pihak institusi dengan kebutuhan akan kegiatan pengembangan ilmu pengetahuan yang terkait pengembangan daerah yang diharapkan masyarakat tidak sejalan dengan keadaan yang sesungguhnya dalam masyarakat dan menjadi permasalahan sosial yang membutuhkan penyelesaian secara ilmiah. Berikut tabel pernyataan masyarakat atas manfaat yang diperoleh masyarkat kota palopo dari hasil penelitian dan pengabdian kepada masyarakat yang dilaksanakan oleh IAIN/STAIN Palopo :

Tabel 2. Manfaat yang dirasakan masyarakat atas Program penelitian dan Pengabdian IAIN/STAIN Palopo

\begin{tabular}{|l|c|c|}
\hline \multicolumn{1}{|c|}{ Uraian } & Jumlah responden & Persentase (\%) \\
\hline Sangat baik & 0 & 0 \\
\hline Baik & 5 & 12,5 \\
\hline Cukup & 3 & 7,5 \\
\hline Kurang & 15 & 37,5 \\
\hline Sangat kurang & 17 & 42,5 \\
\hline Jumlah & 40 & 100 \\
\hline
\end{tabular}

Sumber hasil olah data penelitian, 2015

Dari tabel diatas dapat ditarik kesimpulan bahwa kehadiran IAIN/STAIN Palopo melaksanakan penelitian dan pengabdian kepada masyarakat kurang memberikan mafaat yang signifikan terhadap masyarakat, sementara pelaksanaan penelitian terkait dengan sosial

16 Wawancara dengan Rusdianto, SE , 3 Agustus 2015 
kemasyarakat serta program pengabdian kepada masyarakat dilakukan setiap tahunnya baik oleh dosen maupun mahasiswa. Hal ini terjadi disebabkan oleh a) kurangnya komunikasi antara pihak institusi dan pemerintah, b) program tidak tepat guna , c) kurangnya data masalah sosial kemasyarakatan, d) pelaksanaannya dilakukan atas dasar kebutuhan institusi, e) sifatnya insidentil, dan lain sebagainya

Lebih lanjut Hadhi menekankan bahwa: "Sebaiknya pelaksanaan program penelitian dan pengabdian kepada masyarakan pihak institusi membangun komunikasi dengan pemerintah/kelurahan agar program tesebut dapat dilaksanakan secara bersama sehingga hasil dan implementasi dapat dipertanggungjawab dan dilaksanakan sedini mungkin untuk mengatasi problem sosial dalam kehidupan masyarakat melalui kebijakan pemerintah setempat". 17

Pencapaian hasil yang memberikan dampak positif bagi masyarakat merupakan hal yang menjadi tujuan bagi pelaksanaan suatu kegiatan pengabdian sehingga dibutuhkan terjalinnya hubungan kerjasama antar lembaga melalui penugasan dan rekomendasi bersama antara pihak pemerintah setempat dan pihak institusi agar dalam pelaksanaan progran penelitian dan pengabdian di masyarakat akan memberikan kekuatan hukum dan dukungan dari pemerintah dilapangan sehingga akan mendapatkan keleluasaan dalam melaksanakan kegiatan secara efektif dan efisen sesuai dengan rencana yang telah ditetapkan sebagai bentuk tanggungjawab moral terhadap masyarakat.

Pada dasarnya konsep Universitas Sosial Responsibility/tanggungjawab soaial perguruan tinggi (USR) merupakan konsep tentang pentingnya sebuah lembaga pendidikan membangun dan mengembangkan hubungan timbal balik yang harmonis antara masyarakat dan stakeholder lainnya dengan perguruan tinggi. Secara teoretik, USR dapat didefinisikan sebagai tanggung jawab moral yang melekat pada suatu perguruan tinggi suatu stakeholdernya, khususnya kelompok komunitas atau masyarakat disekitar wilayah kerja dan operasinya dengan berusaha memberikan perhatian terhadap lingkungan dan sosial dalam masyarakat sekitarnya sebagaimana diataur dalam undang-undang nomor 12 tahun 2012 tentang perguruan tinggi.

IAIN/STAIN Palopo sebagai lembaga pendidikan tinggi yang mengembangkan ilmu pengetahuan memiliki komitmen selain melaksanakan pendidikan dan penelitian juga secara berkesinambungan melaksanakan pengabdian kepada masyarakat yang mengacu pada peraturan pemerintah nomor 60 tahun 1999 pasal 3 ayat (4) disebutkan bahwa pengabdian kepada masyarakat adalah kegiatan yang memanfaatkan ilmu

17 Hasil wawancara dengan hadhi Wahyu, AB. Tgl 5 Agustus 2015 
pengetahuan dalam upaya member! sumbangan demi kemajuan masyarakat 18

Program pengabdian kepada masyarakat bagi IAIN/STAIN Palopo di lakukan melalui sumber daya yang dimiliki yakni dosen dan mahasiswa dalam berbagai program kegiatan yang secara berkesinambungan baik dalam bentuk penelitian, pengembangan ilmu pengetahuan, penyebaran hasil penelitian maupun pelayanan kepada masyarakat dan lainnya sebagai bentuk tanggungjawab sosial. Namun dalam pelaksanaannya terdapat kelemahan, diantaranya: Kerjasama yang masih minim dimana pelaksanaan program hanya dilakukan berdasarkan program sepihak saja. Hal ini menimbulkan anggapan dalam masyarakat bahwa pelaksanaan proses pengabdian kepada masyarakat hanya berdasakan kepentingan institusi atau individu semata.

Kurangnya konsultasi terkait permasalahan sosial kemasyarakatan bagi perguruan tinggi sehingga kurang memahami kondisi real dalam masyarakat sehingga manfaatnya kurang memberikan konstribusi yang signifikan yang dirasakan baik bagi masyarakat sekitar maupun pemerintah setempat.

\section{KEBUTUHAN PEMBANGUNAN DAN PENGEMBANGAN MASYARAKAT KOTA PALOPO}

Dalam kehidupan bermasyarakat yang majemuk terdapat berbagai kelompok sosial kemasyarakatan yang berbaur dan berinteraksi antara satu kelompok dengan kelompak lainnya dalam kehidupan sehari-hari dengan tingkat permasalahan sosial berbeda-beda. Dengan perbedaan kelompok dan masalah sosial yang terjadi tersebut yang memungkinkan terjadi konflik sosial yang cenderung cukup tinggi. Kecenderungan terjadinya konflik dalam masyarakat yang heterogen ini tentunya membutuhkan penyelesaian yang arif dan bijaksanan agar rasa aman dan damai masih tetap terjaga sehingga kedamaian dan kesejahteraan dapat tercapai sesuai dengan tujuan pembangunan serta pengembangan daerah terkhusus di kota Palopo.

Berbagai potensi konflik sosial dalam masyarakat mengisaratkan bahwa kebutuhan akan penyelesaian/pemecahan pemasalahan dalam kehidupan bermasyaratakat. Menurut Andi Musakkair bahwa:"Dalam kehidupan bermasyakat khususnya kota palopo potensi konflik dan permasalahan sosial cukup tinggi sehingga dibutuhkan analisi akademik dan pendidikan non formal terkait penataan potensi sumber daya manusia dan sumber daya alam sesuai dengan kondisi lokal daerah seperti bidang ekonomi, badaya, agama dan sosial yang membutuhkan rumusan-rumusan yang efektif membangun dan mengembangan daerah secara tepat guna". ${ }^{19}$

\footnotetext{
18 Peraturan pemerintah no 60 tahun 1999

19 Hasil wawancara Andi Musakkar, S.Ip. tanggal 10 Agustus 2015
} 
Keberagaman agama, budaya, etnis, dan kelompok sosial dimasyarakat kota Palopo mengindikasikam bahwa masalah sosial yang terjadi bukan hanya tertuju pada satu kelompok saja tetapi telah terdapat masalah antar kelompok sehingga penanganannya diperlukan dilaksanakan secara keseluruhan tanpa melihat dari latarbelakang agama, budaya, etnis , golongan dankelompok sosial lainnya.

Pelaksanan program pengabdian kepada masyarakat yang heterogen dibutuhkan pemahaman komperehensif agar berbagai permasalahan yang ada didalamnya dapat diketahui dengan rinci agar masyarakat dapat merasakan konstribusi dan manfaat atas pelaksanaan kegiatan yang dilaksanakan.

Tabel 3. Pernyataan masyarakat terkait pelaksanaan program pengabdian

\begin{tabular}{|l|c|c|}
\multicolumn{1}{|c|}{ IAIN/STAIN Palopo } \\
\hline Uraian & Jumlah responden & Persentase (\%) \\
\hline Sangat Setuju & 17 & 42,5 \\
\hline Setuju & 15 & 37,5 \\
\hline Ragu-ragu & 6 & 15,0 \\
\hline kurang Setuju & 2 & 5 \\
\hline Tidak setuju & 0 & 0 \\
\hline Jumlah & 40 & 100 \\
\hline
\end{tabular}

Sumber olah data penelitian 2015

Berdasarkan tabel diatas masih terdapat $80 \%$ responden berpendapat bahwa masyarakat kota palopo mengharapkan IAIN/STAIN Palopo melaksanakan program penelitian dan pengabdian kepada masyarakat yang beragam kelompok dan golongan sosial dalam menunjang pembangunan dan pengembangan daerah. Hal ini mengindikasikan bahwa kehadiran IAIN/STAIN Palopo ditengah masyarakat diharapkan mampu memberikan berbagai solusi atas permasalahan sosial yang semakin kompleks.

Berbagai kebutuhan pembangunan dan pengembangan potensi sumber daya daerah di kota Palopo terkait dengan penelitian dan pengabdian kepada masyarakat yang heterogen oleh pihak institusi: 20

1. Pendidikan non formal keagamaan, budaya, dan sosial lintas kelompok

2. Pelaksanaan kuliah kerja nyata mahasiswa di daerah pinggiran kota tanpa adanya perbedaan

3. Pelatihan dan pendampingan pengembangan Usaha Mikro, kecil dan Menengah bagi masyarakat.

4. Sosialisasi produk keuangan syariah yang berbasis kewirausahaan.

5. Mediasi kepentingan antar golongan melalui bimbingan sosial

${ }^{20}$ Hasil tabulasi data penelitian 2015 


\section{4 | Zainuddin $S$}

6. Peningkatan mutu kehidupan agama dan keagamaan dalam bermasyarakat

7. Pembinaan soft skill usia remaja dalam kehidupan bermasyarakat

8. Memaksimalisasikan program kerja pembinaan masyarakat berbasis rumah ibadah

9. Penyuluhan kepada masyarakat tentang pengembangan sumber daya daerah berbasis perubahan

10. Pemberdayaan ekonomi masyarakat melalui pemanfaatan sumber daya dan potensi lingkungan.

Sebagai sebuah daerah yang memiliki masyarakat yang heterogen, kota palopo terdiri dari berbagai suku, ras, adat istiadat, kelompok, golongan dan agama serta, strata sosial yang memiliki potensi cukup besar terjadi permasalahan sosial dalam masyarakat. berbagai potensi konflik yang ada diantaranya masalah agama, pendidikan, suku, ras dan sebagainya. Melihat kondisi real masyarakat kota Palopo perlu dipahami secara menyeluruh atas perubahan sosial yang cukup dinamis dan dapat memicu polarisasi konflik sosial termasuk konflik antara agama dan etnis sehingga akan menghasilkan kesenjangan sosial antar kelompok dan golongan yang dapat merusak budaya dan tatanan sosial dalam masyarakat.

Kerusakan nilai-nilai budaya dan tatanan sosial dalam kehidupan bermasyarakat menyebabkan ketidakharmonisan dalam perbauran antar kelompok atau golongan. Dengan terpolarisasinya masyarakat maka diharapkan adanya penyelesaian berdasarkan pada ilmu pengetahuan dan teknologi dari suatu lembaga pendidikan seperti IAIN/STAIN Palopo. Namun keberadaan IAIN/STAIN Palopo ditengah masyarakat heterogen belum memberikan konstribusi yang signifikan dalam pembangunann dan pengembangan masyarakat melalui program penelitian dan pembangunan yang terencana. Beberapa hal kendala yang dihadapi diantaranya 1) kurangnya informasi real masalah sosial kemasyarakatan; 2) proses pelaksanaan kegiatan berdasarkan inisiatif individu yang bersifat insidentil; 3) pelaksanaan tertuju pada kelompok/golongan tertentu, 4. Perencanaan belum terstruktur dan berkesinambungan.

\section{KONTRIBUSI IAIN PALOPO DALAM MERESPON PERMASALAHAN SOSIAL KEMASYARAKATAN}

Dalam rangka pengembangan sumber daya yang menjadi potensi dimiliki suatu daerah untuk melayani dan memenuhi kebutuhan serata memberikan penyelesaian terhadap masalah sosial, ekonomi, budaya dalam kehidupan masyarakat. berbagai permasalahn yang dihadapi oleh masyarakat tidak serta merta mereka mampu menemukan penyelesaian 
yang maksimal sehingga dibutuh suatu kegiatan yang mampu mengurai suatu permasalahan secara komprehensif kemudian menawarkan berbagai alternatif untuk menyelesaikan permasalahan yang dihadapi oleh masyarakat.

Perguruan tinggi merupakan lembaga yang memiliki fungsi yang melekat untuk melaksankan pengembangan ilmu pengetahuan dan teknologi, Penyebar luasankan ilmu pengetahuan, Penerapan ilmu pengetahuan Pemberian bantuan keahlian kepada masyarakat; serta Pemberian jasa pelayanan profesional kepada masyarakat yang merupakan bentuk pertanggungjawaban suatu perguruan tinggi terhadap masyarakat terhadap masyarakat sekitarnya yang lebih dikenal sebagai universitas Sosial Respnsibility (USR). Pelaksanaan USR bagi perguruan tinggi merupakan hal yang pokok dalam pengembangan dan pembangunan suatu daerah. Menurut Markus Pasang salah seorang tokah masyarakat mengatakan bahwa; Perguruan tinggi dan pemerintahan suatu daerah adalah satu kesatuan yang tak dapat dipisahkan dalam pengembangan sumber daya manusia maupun sumber daya alamnya. Bahkan Suatu daerah akan dapat berkembang dengan baik apabila terdapat perguruan tinggi yang secara proaktif melaksanakan fungsi pengbdian kepada masyarakat dengan mengetahui secara tepat tentang kondisi dan permasalahan yang terjadi sehingga mampu menjawab tantangan permasalahan sosial yang di alami oleh masyarakat sekitarnnya. ${ }^{21}$

Implementasi USR oleh IAIN/STAIN Palopo bukan hanya sekedarnya untuk menunaikan kewajiban dan kepentingannya namun diharapkan mampu untuk memberikan manfaat konstruktif bagi masyarakat dalam mengahadapi berbagai masalah sosial kemasyarakatan. Maka untuk itu dilakukan adanya proses ilmiah terhadap suatu permasalahan sosial diantaranya indentifikasi, pengelompokkan, menganalisis berbagai fenomena atau kejadian-kejadian dalam masyarakat sehingga mendapatkan penanganan secara ilmiah dan dapat dipertanggungjawabkan.

Selanjutnya Zulkarnain mengatakan: Agar proses pelaksanaan pengabdian kepada masyarakat bagi IAIN/STAIN Palopo selayak melibatkan diri secara terprogram (observasi bersama dengan pemerintah setempat) kedalam masyarakat untuk mengetahuai hal-hal yang mendesak untuk mendapatkan perioritas, melaksanakan sosialisasi hasil penemuan ilmiah yang dilakukan agar menjadi bahan pertimbangan dalam proses pengambilan kebijakan bagi pemerintah, melakasankana konsultasi secara rutin dengan pihak pemerintahan yang terendah ${ }^{22}$.

Pelaksanakan pengabdian melalui lembaga dan sumber daya yang dimiliki yakni dosen dan mahasiswa yang secara berkesinambungan

${ }^{21}$ Hasil wawancara; Drs. Markus Pasang, M.Si. 2015

22 Hasil wawancara ; Zulkarnain Bahar, SE. 2015 
melaksankan fungsinya untuk melakukan proses analisis permasalahan yang dialami oleh masyarkat kota palopo dengan melaksanakan kegiatan observasi secara mandiri atas kegiatan masyarakat untuk mendapatkan informasi selanjutnya melibatkan diri dalam penyeesaian permasalahan baik berupa pelaksanaan penelitian maupun ikut berpartisipasi pada kegiatan sosial kemasayarakatan dengan menyebarkan ilmu pengetahuan, pengembangan ilmu pengetahuan serta mengaplikasikannya melalui program pembinaan masyarakat, pendidikan nonformal, pendampingan masyarakat dan lain sebagainya. Namun proses pelaksanaannya masih memberikan dampak yang signifikan bagi masyarakat disebabkan oleh berbagai persoalan antara lain sumber infomasi dan penemuan penyelesaian suatu permasalahan masih kurang tepat guna bagi pemerintah dan masyarakat. Tanggapan masyarakat kota Palopo sehubungan dengan pelaksanaan pelaksanaan program penelitian dan pengabdian kepada masyarakat oleh IAIN/STAIN Palopo.dapat dilihat pada Tabel 4 berikut:

Tabel 4. Konstribusi Program Pengabdian dan Penelitian IAIN/STAIN Palopo

\begin{tabular}{|l|c|c|}
\hline \multicolumn{1}{|c|}{ Uraian } & Jumlah responden & Persentase (\%) \\
\hline Sangat baik & 0 & 0,0 \\
\hline Baik & 3 & 7,5 \\
\hline Cukup & 7 & 17,5 \\
\hline Kurang & 11 & 27,5 \\
\hline Sangat kurang & 19 & 47,5 \\
\hline Jumlah & 40 & 100,0 \\
\hline
\end{tabular}

Sumber olah data penelitian 2015

Berdasarkan Tabel 4 dijelaskan bahwa pihak IAIN/STAIN Palopo melaksanakan program penelitian berbasis pengabdian dan pengabdian kepada masyarakat dinilai masih sangat masih kurang memberi konstribusi bagi pemerintah dan masyarakat disebabakan oleh 1). Belum melaksanakan observasi awal dengan konsultasi pemerintah setempat 2) informasi yang disajikan oleh pemerintah/masyarakat belum terfokus pada masalah yang sesungguhnya menjadi perioritas dalam masyarakat. 3) kegiatan tidak tepat guna karena kurang memahami dengan tepat perioritas masalah sosial kemasyarakatan.

Dalam mengidentifikasi masalah sosial kemasyarakatan yang terjadi dalam masyarakat kota palopo, IAIN/STAIN Palopo masih dianggap kurang mampu mengumpulkan informasi yang akurat sehingga konstribusi yang dapat dirasakan oleh masyarakat dan pemerintah masih minim. Hal ini terjadi disebabkan oleh 1). Pelaksanakan observasi awal dengan berkonsultasi pemerintah setempat belum tepat 2) informasi yang disajikan 
oleh pemerintah/masyarakat belum terfokus pada masalah yang sesungguhnya terjadi dalam masyarakat. 3) kegiatan tidak tepat guna karena kurang memahami dengan tepat perioritas masalah sosial kemasyarakatan.

\section{PENUTUP}

Pelaksanaan program pengabdian kepada masyarakat oleh IAIN/STAIN Palopo sebagai bentuk tanggung jawab sosial institusi yang dilaksanakan oleh para dosen dan mahasiswa melalui proses penelitian dan pemberdayaan masyarakat. Namun dinilai masih sangat kurang memberikan konstribusi positif bagi pembangunan dan pengembagan masyarakat kota Palopo. Berbagai permasalahan yang menjadi penyebabnya diantaranya hubungan kerja sama dengan pihak pemerintah kota masih kurang maksimal dan koordinasi secara berkesinambungan dengan pemerintah masih minim serta sosialisasi hasil riset berupa ilmu pengetahuan belum memadai.

Keberadaan IAIN/STAIN Palopo ditengah masyarakat kota Palopo yang heterogen dalam melaksankan tanggungjawab sosial terhadap masyarakat sekitarnya masih kurang memberikan konstribusi yang signifikan terhadap pengembangan potensi dan sumber daya yang dimiliki oleh pemerintah daerah. hal ini disebabkan pihak institusi tidak mendapatkan informasi real di masyarakat, pelaksanaan program atas inisiatif individu pelaksana dan program dirtujukan kepada golongan dan kelompok tertentu dalam masyarakat.

IAIN/STAIN Palopo dalam melaksanakan program pengabdian masyarakat belum melakukan observasi dengan berkoordinasi dengan pemerintah sebagai bentuk pemetaan permasalahan sosial kemasyarakatan guna memberikan nilai tambah bagi masyarakat, belum mendapatkan informasi yang cukup untuk menggambarkan kondisi real masyarakat, serta masih kurangnya program kerja yang menjadi perioritas kegiatan yang tepat guna dan berkesinanmbungan pada masyarakat sehingga pelaksanaan program hanya berdasarkan kepentingan pelaksana

\section{DAFTAR PUSTAKA}

A.B.Susanto. Corporate Social Responsibility. Jakarta: The Jakarta Consulting Group, 2007.

Agus Widyantoro, and M. Hadi Subhan. Tanggung Jawab Sosial Institusi Perguruan Tinggi (Institution Social Responsibility) Sebagai Upaya Mewujudkan Susteinablity Development Bagi Masyarakat Lingkar Kampus. Surabaya: Universitas Airlangga, 2009.

Agussalim Sitompul. Pengabdian Kepada Masyarakat Bagi Perguruan Tinggi Agama Islam - Sudin Pengabdian Kepada Masyarakat Bagi Perguruan Tinggiagama Islam.pdf. Yogyakarta: P3M IAIN Sunan Kalijaga, 1993. 
Amin Widjaja Tunggal. Corporate Social Responcibility. Jakarta: Haryindo, 2008.

Carunia Mulya Firdausy. "Tanggung Jawab Sosial Universitas (Usr) Dan Pengalaman Ristek Dalam Membangun Masyarakat Berbudaya Iptek." Kompasiana, December 8, 2009.

Jujun Suriasumantri S. Filsafat Ilmu Sebuah Pengantar. Jakarta: Pustaka Sinar Harapan, 1998.

Khairuddin. Implementasi Tridarma Perguruan Tinggi Dalam Mendukung Disiplin Nasional. Sumatra Utara: Universitas Sumatera Utara, 2004.

M Ainul Yaqin. Pendidikan Multikultur. Yogyakarta: Pilar Media, 2005.

Margono Slamet. Metodologi Pengabdian Pada Masyarakat. Yogyakarta: P3M IAIN Sunan Kalijaga, 1993.

Philip Kotler. Doing the Most Good for Your Company and Your Cause. New York: Thomas Dunne Books, 2007.

Ratnasari Yunita. Pengaruh Corporate Governance Terhadap Luas Pengungkapan Tanggung Jawab Sosial Perusahaan Di Dalam Sustainability Report. Semarang: Universitas Diponegoro, 2013.

Republik Indonesia. "Undang-Undang Nomor 20 Tahun 2003.” Sekretariat Negara, 2003.

Will Kymlicka. Kewarganegaraan Multikultural. Jakarta: LP3ES, 2003.

Received 26 Oktober 2016, Revised 29 Oktober 2016, Accepted 18 Desember 2016, Available online xx-xxxx-2016 